\author{
Alicja Jaskiernia \\ Uniwersytet Warszawski \\ ORCID: 0000-0001-8412-7217
}

\title{
Pandemia COVID-19 i „nowa normalność” w systemie komunikowania. Wyzwania regulacyjne epoki cyfry
}

\begin{abstract}
Streszczenie
Radykalna transformacja życia na planecie, jaka dokonuje się za sprawą pandemii COVID-19, przyspieszyła konwergencję przestrzeni społecznej i prywatnej za pomocą technologii internetowych. Przedsiębiorstua sektora Big Tech wyrosły na kluczouych uczestników rynku i życia społecznego. W artykule przedstawiono analizę najważniejszych wniosków z debaty na ten temat, przeprowadzonej przez znany amerykański think-tank Pew Research Center na początku 2021 roku. Hipoteza dotyczy konieczności przyjęcia nowego modelu odpowiedzialności platform internetouych w epoce „dualnej konwergencji”, w kontekście poszukiwania nowego paradygmatu relacji ludzi i technologii, odzuierciedlającego w kompleksouy sposób jednostkowe i społeczne koszty korzystania z nowych technologii.
\end{abstract}

Słowa kluczowe: rewolucja cyfrowa, firmy Big Tech, platformy internetowe, pandemia, „nowa normalność".

\section{The pandemic COVID-19 and the "new normal” in the communication system. The regulatory challenges of the Digital Age}

\begin{abstract}
The radical transformation of life on the planet caused by the COVID-19 pandemic has accelerated the convergence of social and private spaces by internet technologies. Big Tech companies have grown into key market and social life players. The article presents the key findings from the debate conducted by the American think-tank Pew Research Center in early 2021. The hypothesis concerns the necessity to adopt a new model of internet platforms accountabilities in the era of "dual convergence", in the context of searching for a new paradigm of human-technology relations, more comprehensive reflecting the individual and social costs of using new technologies.
\end{abstract}

Keywords: digital revolution, Big Tech companies, internet platforms, pandemic, "new normality".

\section{Wprowadzenie}

Radykalna transformacja codziennego życia na planecie, wymuszona przez pandemię COVID-19, skutkuje przyspieszoną konwergencją przestrzeni społecznej i prywatnej za pomocą narzędzi internetouych. Konieczność pozostawania we względnej izolacji, 
zachowania dystansu społecznego, zamrożenia wielu aktywności gospodarczych, kulturalnych, politycznych, a także organizacja życia domowego spowodowały wzrost roli narzędzi komunikacyjnych na różnych poziomach - prywatnym i publicznym. Praca i nauka, uczestnictwo w życiu społecznym i kulturalnym oraz wiele innych aktywności stało się możliue lub w niektórych sytuacjach - dostępne wyłącznie online. Zobaczyliśmy, jak przyspieszyła konwergencja przestrzeni społecznej i prywatnej za pomocą narzędzi internetowych. Mark Deuze formułuje w związku z tymi zjawiskami tezę o dualnej konwergencji ${ }^{1}$ zachodzącej w hybrydowym systemie medialnym ${ }^{2}$, gdzie tradycyjne instytucje medialne działają we wspólnych przestrzeniach z platformami masowej komunikacji spersonalizowanej mediów społecznościowych. Ta medialna konwergencja zachodzi wraz z konwergencją przestrzeni społecznych, miejsc pracy, edukacji i rozrywki, sfer publicznych i prywatnych (supra-locale). Dynamika tych zjawisk wywiera presję na jednostki i całe społeczeństua, które okazały się na taki „skok” w przyszłość nie w pełni przygotowane ${ }^{3}$, podobnie jak na globalną pandemię ${ }^{4}$. Gotowe były głównie korporacje technologiczne, oferujące wirtualne platformy komunikacyjne, świetnie przystosowane do nauki, pracy i poszukiwania informacji rozrywki. Pandemia okazała się klasycznym „szarym łabędziem”, chociaż - jak twierdzi wielu ekspertów nie powinna nikogo dziwić lub szokować. W wymiarze egzystencjalnym pandemia podkopała naiwną wiarę współczesnego człowieka, że „potrafi przechytrzyć i pokonać śmierć. To rewolucyjnie nowa postawa”. Ludzkość musiała z pokorą przypomnieć sobie, że

nie jesteśmy oddzieleni od śuiata swoim „człowieczeństuem” i wyjątkowością, ale świat jest rodzajem wielkiej sieci, w której tkwimy, połączeni z innymi bytami nieuidzialnymi nićmi zależności i upływów. [...]. Na naszych oczach rozwiewa się jak dym paradygmat cywilizacyjny, który nas kształtował przez ostatnie dwieście lat: że jesteśmy panami stuorzenia, możemy uszystko i świat należy do nas. Nadchodzą nowe czasy?

Szybkość i guałtowność rozprzestrzeniania się epidemii ujawniły globalny, ponadklasowy charakter oraz suoistą „demokratyczność” sytuacji kryzysouych we uspółczesnym połączonym śuiecie, uświadamiając uszystkim, że u społeczeństwie

${ }^{1}$ M. Deuze, Challenges and Opportunities for the Future of Media Mass Communication Theory and Research: Positionality, Integrative Research, and Public Scholarship, „Central European Journal of Communication" 2021, Vol. 14, No. 1(28), s. 5.

2 A. Chaduick, The Hybrid Media System, Oxford University Press, Oxford, UK 2013, s. 3-4.

3 Ch. Fuchs, Everyday Life and Everyday Communication in Coronavirus Capitalism, „Communication, Capitalism \& Critique” 2020, Vol. 18 (1), s. 375-399.

${ }^{4}$ R.M. Henig, Dlaczego świat nie byt gotowy na wirusa? Czy ignorowaliśmy sygnaty?, „National Geographic”, 3.08.2020, https://www.national-geographic.pl/artykul/koronawirus-brak-przygotowania-na-pandemie-dlaczego-ignorowalismy-sygnaly (dostęp: 12.08.2021).

${ }^{5}$ I. Krastew, Nadeszło jutro. Jak pandemia zmienia Europe, przeł. M. Sutouski, Wydawnictuo Krytyki Politycznej, Warszawa 2020, s. 11.

${ }^{6}$ N. Harari Yuval, Wirus a śmierć, „Forum” 2020, nr 11, s. 27.

${ }^{7}$ Okno. Olga Tokarczuk o pandemii, 3.04.2020, CULTURE.PL, https://culture.pl/pl/artykul/ okno-olga-tokarczuk-o-pandemii (dostęp: 12.08.2021). 
światowego ryzyka ${ }^{8}$ nieszczęście może dosięgnąć każdego. Przebieg i skutki pandemii muszą skłaniać do stawiania pytań o zdefiniowanie charakteru owych „nowych czasów” czy też „nowej normalności”, domagając się ustanowienia punktu odniesienia. Wymaga to przedefiniowania dotychczasouych hierarchii wartości, sensu starych pojęć i zrozumienia porządku rozwoju epoki czwartej rewolucji przemysłowej9. Pandemia stała się więc silnym impulsem do kreowania wizji przyszłości, która toczyć się będzie w epoce dominacji nowych technologii według nowych paradygmatów, wyznaczanych między innymi przez „oduróconą atomizację” publiczności, multiplikację kanałów, medializację kolejnych obszarów życia społecznego (np. ochrony zdrowia) i postępujący „mediacentryzm” wielu sfer życia ${ }^{10}$.

Kierunki tych rewolucyjnych przemian, które wyróżnił medioznawca Mark Deuze, potwierdza pisarz Jacek Dukaj. Jego zdaniem, uraz z nastaniem ery cyfry ${ }^{11}$, możemy obserwować następujące procesy: 1) coraz głębsze zakotwiczanie informacji oraz ludzkich doświadczeń i przeżyć u przestrzeni cyfrowej; 2) wzrost zagrożeń manipulacją na niewyobrażalną skalę w wyborach (politycznych, konsumenckich) w związku z dostępem do danych i profilowaniem; 3) wyrány związek filtrowania treści z kontrolą myśli i wolności słowa.

Pandemia spowodowała przyspieszenie wielu procesów u zakresie upouszechniania technologii komunikacyjnych oraz zmian w konsumpcji medió $w^{12}$, w dodatku dynamizując rozwój w wielu dziedzinach (sztuczna inteligencja, robotyka, serwisy strumieniowe jako platformy dostarczania treści audiowizualnych). W kontekście ekonomicznym zmiany te skutkują dalszą dominacją globalnych firm z sektora komunikacji internetowej, pochodzących głównie z amerykańskiej Doliny Krzemowej (tzw. GAFAM), a także Chin $(B A T)^{13}$. Shoshana Zuboff, uykładowczyni na Uniwersytecie Stanforda i autorka głośnej książki Wiek kapitalizmu inwigilacji..., podkreśla bezprecedensowe sukcesy u kreowaniu nowego ekosystemu kapitalizmu globalnego przez globalne korporacje sektora nowych technologii, dla których "surowcem” stały się dane osobowe, a przestrzenie życioue stały się przestrzeniami nieustającego marketingu ${ }^{14}$. Korporacje takie jak Google, Facebook, a także Verizon czy Comcast przejęły kontrolę w wielkich mediach, systemie

${ }^{8}$ U. Beck, Społeczeństwo światowego ryzyka. W poszukiwaniu utraconego bezpieczeństwa, przeł. B. Baran, Wydawnictuo Naukoue Scholar, Warszawa 2012.

${ }_{9}^{9}$ K. Schwab, Czwarta rewolucja przemysłowa, przeł. A.D. Kamińska, Studio EMKA, Warszawa 2018.

${ }^{10}$ M. Deuze, The Role of Media and Mass Communication Theory in the Global Pandemic, „Communication Today” 2020, Vol. 11, No. 2, s. 5-16.

11 J. Dukaj, Wolność myśli albo demokracja, „Gazeta Wyborcza. Magazyn Wolna Sobota”, 5.06.2021, s. 10 .

12 Digital News Report 2021, out on 23 June, Reuters Institute, https://reutersinstitute.politics. ox.ac.uk/risj-review/digital-neus-report-2021-out-23-june (dostęp: 12.08.2021).

${ }^{13}$ Skróty od nazw wielkiej czwórki czy piątki firm z USA (Google, Apple, Facebook, Amazon i Microsoft) oraz chińskich: Baidu, Alibaba i Tencent; por. m.in. S. Galloway, Wielka Czwórka. Ukryte DNA: Amazon, Apple, Facebook i Google, przeł. J. Kubiak, Dom Wydauniczy Rebis, Poznań 2019.

${ }_{14}$ S. Zuboff, Wiek kapitalizmu inwigilacji. Walka o przyszłość ludzkości na nowej granicy władzy, przeł. A. Unterschuetz, Wydawnictwo Zysk i S-ka, Poznań 2020, s. 233-235. 
finansouym, telekomunikacji i wielu innych sektorach, przy czym nie podlegają należytej kontroli ani przez konkurencję rynkową, ani przez państwa ${ }^{15}$, działając niejako w sferze, usankcjonowanego przez bierność regulacyjną państw, swoistego bezprawia.

Ulrich Beck podkreśla inną immanentną cechę tego etapu ewolucji kapitalizmu -,dziką niepewność” zmiennych, które znajdują swój wyraz na przykład w „dzikich” przychodach i zyskach rynków finansowych oraz monopolizowaniu całych sektorów gospodarki, zułaszcza przemysłu informacji ${ }^{16}$. Kryzys pandemiczny wyostrzył brak regulacji oraz sprzeczności pomiędzy strategiami globalnymi tych firm a na przykład bezpieczeństuem społecznym (infodemia) ${ }^{17}$ oraz narodowym. Zaniepokojenie, zułaszcza z powodu rosnącej aktyuności korporacji technologicznych z Chin na rynku globalnym, wyrażają między innymi Stany Zjednoczone i kraje europejskie, chociaż widać tu także daleko idącą niespójność postaw ${ }^{18}$. Spirala konkurencji w sektorze nowych technologii pomiędzy Stanami Zjednoczonymi a Chinami zrodziła tezę o „zimnej wojnie” amerykańsko-chińskiej na tle zagrożenia chińskimi sukcesami w dziedzinie innowacji oraz inwestycji zagranicznych firm z tego państwa, także na terenie Unii Europejskiej ${ }^{19}$.

\section{Dylematy „nowej normalności”}

W debatach środowisk naukouych i eksperckich rola nowych technologii komunikacyjnych jest postrzegana jako kluczowe centrum, z którego promieniują uszelkie nowe zjawiska, generujące nowe potrzeby i zachowania, powodujące widoczne efekty na wielu polach - od polityki do jakości życia ludzi ${ }^{20}$.

Jak uygląda „nowa normalność” i jednocześnie jak bardzo jesteśmy uzależnieni jako jednostki i społeczeństwa - od nowych technologii komunikacyjnych oraz platform, które oferują „niezbędne” ich współczesnym użytkounikom, usługi i aplikacje, ukazała sześciogodzinna awaria Facebooka 4 października 2021 roku ${ }^{21}$. Około 3,3 mld ludzi

${ }_{15}$ L. Dowbor, Społeczeństwo w poszukiwaniu nowych kierunków, „Le Monde Diplomatique”, marzec-kwiecień 2021, s. 34-35.

${ }^{16}$ U. Beck, Społeczeństwo światowego ryzyka..., s. 80-81.

17 A. Jaskiernia, Information pollution in a digital and polarized world as a challenge to human rights protection - the Council of Europe's approach, „Review of European and Comparative Law" 2021, Vol. XLVI, No. 3, s. 7-26.

${ }^{18}$ S. Lau, EU slams China's authoritian shift' and broken economic promises, „POLITICO”, 25.04.2021, https://www.politico.eu/article/eu-china-biden-economy-climate-europe/ (dostęp: 12.08.2021).

${ }_{19}$ M. Orłouski, Globalny wyścig o zachowanie podmiotowości, Idee dla Polski. Obywatelski thinkletter, https://wuw.kongresobywatelski.pl/wp-content/uploads/2019/01/mariusz_orlowski-globalny_wyscig_o_zachowanie_podmiotowosci.pdf (dostęp: 2.11.2021).

20 J. Anderson, L. Rainie, E.A. Vogels, Experts Say the 'New Normal' in 2025 Will Be Far More Tech-Driven, Presenting More Big Challenges, Pew Research Center February 18, 2021, https://www.pewresearch.org/internet/2021/02/18/experts-say-the-new-normal-in-2025-will-be-far-more-tech-driven-presenting-more-big-challenges/ (dostęp: 12.08.2021); M. Orłouski, Globalny wyścig..., s. 6-8.

${ }^{21}$ S. Dang, Maintenance error caused Facebook's 6-hour outage, company says, https:// wuw.reuters.com/technology/facebook-says-maintenance-error-caused-mondays-6-hour-outage-2021-10-05/ (dostęp: 5.10.2021). 
zostało odciętych od ważnych dla nich „życiouych” platform (Facebooka, Instagrama, Messengera, WhatsAppa). Abstrahując od wizerunkowych i finansowych strat poniesionych przez firmę, wymiar tej awarii uświadamia, że to wielkie korporacje internetowe stały się głównymi beneficjentami lockdownów, onlajnów oraz rywalizacji o uwagę odbiorców mediów. Nawet jeśli przyjmiemy, że ludzie pragną powrotu do „normalności”, w tym tęsknią za kinem, teatrem czy koncertem na żywo, to praudziwe są ustalenia: 1) że na obecną sytuację - przejścia skrótem do przyszłości, jaką jest „era cyfry" - gotowe były głównie globalne korporacje technologiczne, oferujące wirtualne platformy komunikacyjne; 2) trwa najintensywniejszy wyścig technologiczny w historii ludzkości, którego stawka wykracza daleko poza prymat stricte gospodarczy i ich natura nie jest też czysto technologiczna ${ }^{22}$.

Shoshana Zuboff, uspomniana ucześniej, zauważa, że okres, w który wchodzi ludzkość, paradoksalnie nie jest definiowany poprzez technologie, upouszechnione w społeczeństwie sieci, opisanym przez Manuela Castellsa ćwierć wieku temu ${ }^{23}$, ale poprzez logikę, która za nimi stoi i nimi zarządza ${ }^{24}$. Pandemia, ale też suma wcześniejszego zderzenia z zagrożeniami płynącymi z sieci, uświadomiła cyfrowym tubylcom, że same umiejętności użytkowania narzędzi, które stały się niezbędne w kontaktach z innymi ludźmi, w pracy czy edukacji, nie wystarczą. Konieczny stał się konsens pomiędzy technologią, która sama $u$ sobie nie jest neutralna ${ }^{25}$, a potwierdzeniem dominującej kontrolnej roli człowieka.

O konieczności zastosowania nowego paradygmatu i podejścia jakościouego do nowych technologii przekonują zarówno badacze mediów ${ }^{26}$, jak i eksperci. Szeroko zakrojoną debatę na ten temat przeprowadził znany amerykański think-tank Pew Research Center. Zaproszono do niej 915 osób z różnych obszarów życia społecznego: badaczy, prawników, ekspertów z dziedziny nowych technologii oraz aktywistów z sektora pozarządowego. Z debaty wyłania się wizja kluczouych zmian w różnych dziedzinach życia ${ }^{27}$, spowodowanych - przyspieszonym przez pandemię - wkroczeniem ludzkości w „technologiczną przyszłość”. Wszyscy podkreślali głęboką naturę zachodzących zmian, wręcz rekonfigurujących podstawy ludzkiej egzystencji, która musiała na dobre oswoić się z warunkami świata wirtualnego. Nie wahali się używać określeń odnoszących się do ich skali i głębokości, takich jak: „masoue zakłócenia”, „bezprecedensowe wyzuanie”, „niewyobrażalna skala”, „przerwana równowaga”

${ }^{22}$ M. Orłouski, Globalny wyścig..., s. 1-2.

${ }_{23}$ M. Castells, Społeczeństwo sieci, przeł. M. Marody i in., Wydawnictwo Naukoue PWN, Warszawa 2008.

${ }^{24}$ S. Zuboff, Wiek kapitalizmu inwigilacji..., s. 29.

${ }^{25}$ Tzu. pierusze prawo technologiczne Kranzberga brzmi $w$ oryginale ( $w$ j. angielskim): „Technology is neither good nor bad; nor is it neutral”; M. Kranzberg, Technology and history: „Kranzberg's Laws”, „Bulletin of Science, Technology \& Society”, First Published February 1, 1995, https://journals.sagepub.com/doi/abs/10.1177/027046769501500104 (dostęp: 12.08.2021).

${ }^{26}$ E. Morozov, To Save Everything, Click Here, Penguin Books, London 2013, M. Deuze, The Role of Media...

${ }^{27}$ J. Anderson, L. Rainie, E.A. Vogels, Experts Say the 'New Normal' in 2025... 
czy „punkt załamania”28. Uniwersalizm ich spostrzeżeń dotyczył przede wszystkim zakotwiczenia zmian $\mathrm{w}$ fundamentalnym paradygmacie dominującej roli technologii oraz wynikającej z natury tych zmian konieczności wypracowania nowej perspektywy postrzegania relacji ludzi z narzędziami technologicznymi. Filary nowego paradygmatu powinny u szerszym niż dotychczas wymiarze opierać się na konieczności wdrożenia nowej jakości tychże relacji ${ }^{29}$. Fundamentalna akceptacja wagi nowych technologii komunikacyjnych w epoce „czwartej rewolucji przemysłowej”30 nie może abstrahować od wagi „ludzkiego wymiaru” jako elementarnego czynnika rozstrzygającego o jakości nowych środków technologicznych.

Wśród obszarów uspomnianej debaty Pew Research Center można uyróżnić kilka wątków skoncentrowanych wokół kwestii konieczności kontroli działalności gigantów sektora zwanego Big Tech oraz zwiększenia bezpieczeństwa i zapeunienia lepszej jakości - w sensie aksjologicznym, a nie technologicznym - komunikacji społecznej. Suma pozytywów dającej się przeuidzieć owej „nowej normalności” była równoważona przez masę rozpoznanych już negatywów. Potencjał pozytywów uynika głóunie z błyskawicznego upouszechnienia narzędzi komunikacji, które umożliwiają wiele ułatwień w pracy i załatwianiu spraw życiowych oraz perspektyw kreowania jeszcze dość nowych systemów (aplikacje „smart”, kreacje wirtualnej rzeczywistości, sztuczna inteligencja). Eksperci wiązali zagrożenia głównie z wykorzystaniem technologii dla celów dezinformacji, propagandy i wojen informacyjnych, tworzenia podziałów społecznych, wprowadzania chaosu czy deprecjacji racjonalnych argumentów w debacie publicznej. Kontrola jednostek i społeczeństwa w skali masowej, już uprowadzana w niektórych rejonach globu na masową skalę ${ }^{31}$, może zostać poszerzona na modłę chińską, do dyscyplinowania obywateli, prześladowania niepokornych, utrudniania prawa do wypowiedzi i samoorganizacji obywateli. Skutkiem tych zjawisk może być dalsza atrofia demokracji, w skali globalnej rosną różnice w standardach wolności w krajach demokratycznych i autokratycznych. Demokracja może znaleźć się w odwrocie, zwiększy się liczba tak zwanych demokracji „ułomnych” i niepełnych, a tym samym być może świat ukroczy w erę postdemokratyczną, w której - zgodnie z retoryką „moralnej równoważności” można nie dostrzegać znaczącej różnicy pomiędzy demokracją a autokracją ${ }^{32}$.

\section{Media tradycyjne - zderzenie z GAFAM i „nową normalnością”}

Media, z racji egzystencjalnego uzależnienia od technologii komunikacyjnych, z konieczności muszą utrzymać się w awangardzie zmian, jakie niesie czwarta rewolucja przemysłowa. Te tradycyjne, zwłaszcza prasa drukowana, wskutek erozji dotychczasowych

\footnotetext{
${ }^{28}$ Ibidem: w języku angielskim raportu Pew Research Center: „massive disruption”, „unprecedented challenge”, „unthinkable scale”, „punctuated equilibrium”, ,inflection point”.

${ }^{29}$ Ibidem.

${ }^{30}$ K. Schwab, Czwarta rewolucja...

${ }^{31}$ K. Strittmatter, Chiny 5.0. Jak powstaje cyfrowa dyktatura, przeł. A. Gadzała, Grupa Wydawnicza Foksal, Warszawa 2018.

32 A. Applebaum, Zmierzch demokracji. Zwodniczy powab autorytaryzmu, przeł. P. Tarczyński, Wydawnictuo Agora, Warszawa 2020, s. 188.
} 
podstaw modelu ekonomicznego, płacą cenę za dekadę deregulacji i obojętności uobec bezprecedensowego wzrostu tak zwanych start-upów. Firmy technologiczne przez dekady korzystały z wielu przywilejów jako „media społecznościowe””33, prowadząc jednocześnie regularną działalność biznesową. Media jakościowe, spełniające lepiej lub gorzej rolę „kamienia węgielnego demokracji”, dostarczające zawartość lepiej zweryfikowaną i bardziej wiarygodną $a^{34}$, nie potrafiły w korzystny dla siebie sposób odpowiedzieć na wyzwania epoki cyfrowej.

Pandemia niewątpliwie wyostrzyła także wiele kuestii dotyczących ram i warunków funkcjonowania mediów, zarówno jako podmiotów gospodarczych, jak i politycznych. Znaczna część debaty społecznej przeniosła się do mediów społecznościouych, co wymaga przystosowania formuły działania mediów tradycyjnych do często krańcowo odmiennych zasad czy wręcz ich braku. W zmianie modelu komunikacji istotne okazało się zanikanie barier pomiędzy producentami zawartości medialnej a jej konsumentami (prosumentami) i dewaluacja tradycyjnego dziennikarstwa ${ }^{35}$. W warunkach drapieżnej konkurencji i polaryzacji debaty publicznej media poddają się globalnym tendencjom tabloidyzacji, dewaluacji jakościowej i zanikaniem profesjonalizmu ${ }^{36}$. Grozi to zrównaniem z poziomem wielu platform i mediów społecznościouych, zdominowanych przez ekstremalne głosy, często przejmujące dyskursy publiczne ${ }^{37}$, gdzie produkuje się „alternatywne fakty”, wartościoue zaś idee i pomysły są spychane na margines ${ }^{38}$.

Sukces mediów społecznościowych, porównywalny z niegdysiejszą popularnością prasy tabloidowej, wykorzystującej uproszczoną populistyczną narrację ${ }^{39}$, potwierdza

${ }_{33}$ Zob. m.in.: S. Galloway, Wielka czwórka...; R. McNamee, Nabici w Facebooka. Przestroga przed katastrofa, przeł. K. Pułauski, Media Rodzina Sp. z o.o., Poznań 2019; B.J. Mendelson, Social Media to ściema, przeł. M. Machnik, Wydawnictwo Helion, Gliwice 2014.

${ }^{34}$ R. Fletcher, Perception of fair news coverage among different groups, 2021 Digital News Report, Reuters Institute, https://reutersinstitute.politics.ox.ac.uk/digital-news-report/2021/ perceptions-fair-news-coverage-among-different-groups (dostęp: 17.08.2021).

35 Zob. m.in.: J. Curran, Media and Power, Routledge, London-New York 2002, s. 52; H. Jenkins, S. Ford, J. Green, Rozprzestrzenialne media. Jak powstają wartości i znaczenia w usieciowionej kulturze, przeł. M. Wróblewski, Wydawnictwo Uniwersytetu Łódzkiego, Łódź 2018; P. Levinson, Nowe nowe media, przeł. M. Zawadzka-Strączek, Wydawnictuo WAM, Kraków 2010.

36 Zob. m.in. S. Allen, Newsy w sieci. Internet i dziennikarstwo, przeł. A. Sadza, Wydaunictuo Uniwersytetu Jagiellońskiego, Kraków 2008; C. Bond Potter, Political Junkies. From Talk Radio to Twitter, How Alternative Media Hooked Us and Politics and Broke Our Democracy, Basic Books, New York 2020.

37 J. Anderson, L. Rainie, E.A. Vogels, Experts Say the 'New Normal' in 2025..., s. 77-78; por. J. Ebner, Coraz ciemniej. Ekstremiści w sieci, przeł. A. Zieliński, Polityka Sp. z o.o., Warszawa 2020.

${ }^{38}$ L. Rainie, J. Anderson, J. Albright, The Future of Free Speech, Trolls, Anonymity and Fake News Online, Pew Research Center, March 2017, https://www.peuresearch.org/internet/2017/03/29/the-future-of-free-speech-trolls-anonymity-and-fake-news-online/; A. Mitchell et al., Political Divides, Conspiracy Theories and Divergent News Sources Heading Into 2020 Election, Pew Research Center, September 16, 2020, https://www.journalism.org/2020/09/16/ political-divides-conspiracy-theories-and-divergent-news-sources-heading-into-2020-election/ (dostęp: 17.08.2021).

${ }^{39}$ C. Bond Potter, Political Junkies..., s. 52, 253. 
opinie, że u ekosystemie cyfrowego oceanu informacji to nie media a giganci technologiczni „ramują” strumienie informacji, zasoby wiedzy i sposób życia miliardów ludzi na całej planecie. Manuel Castells zauważa, że w istocie stanowią one ośrodki władzy, sprawując „władzę sieciową” nad przekazywanymi komunikatami ${ }^{40}$. Wykreowane w ten sposób środowisko, w którym ludzie są aktywami, można zmonetyzować, nie tylko powiększając zyski akcjonariuszy, lecz także zagarniając tym samym coraz to nowe i głębsze pokłady władzy ${ }^{41}$. Skutkiem pandemii może się okazać jeszcze większa koncentracja władzy w rękach niewielkiej liczby kluczowych aktorów ${ }^{42}$. Tymczasem, jak trafnie zauważa analityczka Altimeter Group Susan Etlinger, „technologia powinna być narzędziem - nie bronią, religią lub rządem" "43. Jej zdaniem korporacje technologiczne w postpandemicznej rzeczywistości zyskają zbyt dużo władzy „ramując nasze życie: co wiemy, jak żyjemy, czyniąc z nas aktywa rosnących przychodów suoich akcjonariuszy ${ }^{44}$.

Opinię o zbyt wielkiej władzy Big Tech podzielają inni eksperci, obawiając się, że rosnąca monopolizacja stanie się hamulcem dla innowacyjności, ograniczania konkurencyjności świata gospodarki, a także dominującą siłą w kreowaniu polityki ${ }^{45}$. Nadzieja na pozytywne rozwiązania - zdaniem ekspertów - jest ulokowana w młodym pokoleniu. Facebook oraz inne platformy, pod wpływem żądań świadomych i obeznanych z technologiami młodych ludzi, zostaną zmuszone do zaostrzenia reguł własnej odpowiedzialności. Kuestia zwiększonej odpowiedzialności za udostępniane treści dotyczy zresztą wszystkich mediów, także tych tradycyjnego mainstreamu, które w trakcie pandemii zachouują się nieraz bardzo niejednoznacznie. Jednakże świadomość szkód, jakie powoduje dezinformacja (nie tylko w trakcie pandemii), zułaszcza poprzez praktyki mediów społecznościouych, w skali globalnej wzrasta ${ }^{46}$. Zidentyfikowane i odczuwalne koszty korzystania z mediów społecznościowych stały się na tyle groźne, że wymagają bardziej efektywnego podejścia regulacyjnego. Eksperci przewidują, że platformy będą musiały pogodzić się z regulacjami i ograniczeniami, wprowadzanymi u zależności od typu technologii ${ }^{47}$.

Kwestie ochrony danych użytkowników, respektowania praw własności intelektualnej, ochrony dzieci czy płacenia uczciuyych podatków przez firmy sektora Big

${ }_{40}$ M. Castells, Władza komunikacji, przeł. J. Jedliński, P. Tomanek, Wydawnictuo Naukoue PWN, Warszawa 2013, s. 410.

${ }^{41}$ Ibidem.

${ }^{42}$ E. Dwoskin, Tech giants are profiting - and getting more powerful - even as the global economy tanks, April 27, 2020, „,The Washington Post”, https://wuw.uashingtonpost.com/ technology/2020/04/27/big-tech-coronavirus-winners/ (dostęp: 17.08.2021).

${ }^{43}$ J. Anderson, L. Rainie, E.A. Vogels, Experts Say the 'New Normal' in 2025..., s. 24.

${ }^{44}$ Ibidem.

${ }^{45}$ E. Warren, Here's how we can break up Big Tech (March 8, 2019), https://medium.com/@ teamwarren/heres-how-we-can-break-up-big-tech-9ad9e0da324c (dostęp: 17.08.2021); K. Kitchen, The New Superpowers: How and Why the Tech Industry is Shaping the International System, „National Affairs”, No 48, Summer 2021, https://nationalaffairs.com/the-new-superpowers-how-and-why-the-tech-industry-is-shaping-the-international-system (dostęp: 17.08.2021).

${ }^{46}$ R. Fletcher, Perception of fair news coverage...

47 J. Anderson, L. Rainie, E.A. Vogels, Experts Say the 'New Normal' in 2025... 
Tech, są podejmowane coraz śmielej przez rządy i organizacje międzynarodowe, od Australii po Europę, od Unii Europejskiej po OECD ${ }^{48}$. Zułaszcza że, poza kuestiami ekonomicznymi, problemem geopolitycznym szczególnie groźnym zjawiskiem stała się cyberprzestępczość, której ataki wywołują zakłócenia w infrastrukturze krytycznej. Działania różnych organizacji ekosystemu cyberwojennego, często powiązanych z władzami niektórych krajów (np. Korea Północna, Rosja), pociągają za sobą ogromne straty ekonomiczne i społeczne ${ }^{49}$. Społeczność międzynarodowa oraz rządy poszczególnych państw próbują odpowiadać na to wyzuanie, porównywalne z zagrożeniem ataków terrorystycznych w świecie rzeczywistym.

Oczywiście pogodzenie regulacji prawnych z guarancjami suobody prawa do wypowiedzi stanowi ogromne wyzwanie dla wszystkich uczestników procesów kształtowania ładu medialnego. Dla właścicieli Facebooka, Twittera i innych platform oraz dla polityków i świata prawniczego stało się oczywiste, że uszyscy muszą w końcu wykazać się większą kreatywnością, odpowiedzialnością i respektem wobec konieczności uporządkowania różnych kuestii - od reklamy politycznej po dyskurs obywatelski. Nadal bowiem przestrzeń wirtualnych dysput jest odbierana jako „dziki Zachód”, gdzie nie obowiązują zasady prawdy i reguły uczciwości, dozwolone jest bowiem uszystko, jeśli wspiera przychody z reklam ${ }^{50}$. Platformy internetowe, które stały się - bezwiednie, ale nie bez winy - głównym kanałem „prawd alternatywnych”, teorii konspiracyjnych oraz ekstremalnych treści, nie mogą być samoregulowane przez właścicieli infrastruktury komunikacji, czyli prywatne firmy, kreując model „prywatyzacji cenzury" ${ }^{1}$. Być może konieczne będzie stworzenie wspólnych globalnych ram i procedur certyfikowanych przez gremia międzynarodowe. Przedstawiciele świata prawniczego pokładają wprawdzie nadzieje w aktywności samych użytkowników na rzecz lepszej etyki mediów społecznościowych, lecz także aktywności tradycyjnych aktorów polityk medialnych, władz państwowych i organizacji, mających demokratyczny mandat do ustanawiania standardów regulacyjnych. Ograniczanie na platformach nieuczciuych praktyk w kwestiach społecznych i politycznych może spotkać się z pouszechną aprobatą, kiedy równie pouszechna będzie świadomość szkodliwości konsekwencji szerzenia dezinformacji ${ }^{52}$.

\section{Wnioski}

Debaty dotyczące postpandemicznej „nowej normalności” w ekosystemie komunikacji coraz dosadniej identyfikują negatywy, deficyty i zagrożenia, które wcześniej były mniej lub bardziej ignorowane. Na przykład trudniej jest zaprzeczać konieczności regulacji

\footnotetext{
${ }^{48}$ Ibidem, s. 94.

49 A. Jaulmes, Wojna na kliknięcia [Le Figaro], „Gazeta Wyborcza. Magazyn Wolna Sobota”, 19-20.06.2021, s. 27.

${ }^{50}$ J. Anderson, L. Rainie, E.A. Vogels, Experts Say the 'New Normal' in 2025..., s. 41.

${ }^{51}$ L. DeNardis, The Global War of Internet Governance, Yale University Press, New HavenLondon 2014, s. 11-16.

${ }^{52}$ J. Anderson, L. Rainie, E.A. Vogels, Experts Say the 'New Normal' in 2025..., s. 126.
} 
działalności platform, skupiając się jedynie na dobrodziejstwach nouych technologii, lekceważyć skutki społeczne dezinformacji czy polaryzacji debaty. Dotychczasowe rezultaty u tym zakresie, podejmowane na różnych forach (w tym ogólnoświatowym, przez ONZ), nie napawają optymizmem, ponieważ platformy wymykają się logice regulacyjnej w tradycyjnych kategoriach prawa i porządku ${ }^{53}$. Przyjęcie przejrzystych, zrozumiałych i podlegających demokratycznej odpowiedzialności, regulacji i zasad, akceptowanych pouszechnie przez użytkowników, jest po prostu lepsze niż „kontrola sprawowana przez na wpół ukryty związek uładzy publicznej z prywatną”, „eksportu cenzury" do podmiotów prywatnych i władzy korporacji technologicznych ${ }^{54}$.

Okres pandemii koronawirusa, w tym także infodemia, szerzona na platformach społecznościouych, uświadomiły państuom i ułaścicielom platform, że może ona być róunie groźna w skutkach jak sama pandemia. Może atakować różne środowiska, od polityków i naukouców po lekarzy i dziennikarzy. Eksperci panelu Pew Research Center dość zgodnie za możliuy uznali scenariusz, że paradoksalnie okres pandemii, w którym tak bardzo człowiek został uzależniony od technologii, będzie punktem zurotnym w zbyt optymistycznym podejściu do technologii. Można zidentyfikować duie kluczowe kuestie nowego paradygmatu, które stanowią ramę tego podejścia: 1) pouszechność i uszechobecność platform wymusza większą transparentność oraz odpowiedzialność za skutki ich działalności; 2) zwiększa się waga dostępu do rzetelnej informacji, w tym także do dzielenia się zueryfikowaną wiedzą ${ }^{55}$. Wypracowanie powszechnie akceptowalnych rozuiązań w kwestii odpowiedzialności platform w związku z dezinformacją, smogiem informacyjnym i treściami bezprawnymi musi zostać ściśle powiązane z nową jakością w relacjach pomiędzy człowiekiem a technologiami komunikacyjnymi. Jeden z uczestników panelu, emerytowany profesor informatyki z Uniwersytetu Kalifornijskiego w Berkeley, podkreślił w swojej opinii, że w świecie zdominowanym przez technologie komunikacyjne łatuo o poszukiwanie rozwiązań problemów i eliminowanie błędów jedynie na gruncie samej technologii, tymczasem tak samo ważny jest „czynnik ludzki”:

Moi przyjaciele ze śuiata komputerów są skłonni wierzyć, że rozwiązaniem problemów złej technologii jest zastąpienie jej dobrą technologią. Ale jeśli chodzi o społeczne skutki technologii, mam staromodny pogląd, że zuykkle liczą się ludzkie decyzje, a nie technologiczne imperatywy ${ }^{56}$.

Mark Deuze przekonuje o konieczności jak najszerszego zastosowania podejścia jakościouego $\mathrm{w}$ badaniach nad komunikowaniem $w$ cyfrowym ekosystemie ${ }^{57}$. Przyjęcie perspektywy proponowanej przez niego dualnej konwergencji to zachęta do określenia wagi „ludzkiego wymiaru” wobec czynnika technologicznego jako centrum cyfrowego

\footnotetext{
${ }_{53}$ M. Castells, Spoteczeństwo sieci..., s. 124.

${ }^{54}$ T. Garton Ash, Wolne stowo. Dziesięć zasad dla połaczonego świata, przeł. M. Godyń,

F. Godyń, Społeczny Instytut Wydawniczy Znak, Kraków 2018, s. 579-583.

55 J. Anderson, L. Rainie, E.A. Vogels, Experts Say the 'New Normal' in 2025...

${ }^{56}$ Ibidem, s. 54.

${ }^{57}$ M. Deuze, Challenges and Opportunities..., s. 18.
} 
ekosystemu, stawiania pytań o jego „wartość” w jednostkowym i społecznym, a nie biznesowym wymiarze. Podobne podejście proponuje Tricia Wang, która uważa, że poza Big Data potrzebne są thick data, czyli dane "gęste”, oraz nowe wzorce i metody badawcze $^{58}$. Zakładają one szersze zastosowanie, na każdym etapie projektowania nowych narzędzi i aplikacji, angażowania socjologów, psychologów, pedagogów oraz ekspertów z innych dziedzin niż specjalistów od tak zwanych tech. Takiego podejścia do technologii, które w większym stopniu będzie uwzględniać jednostkowe i społeczne koszty korzystania z ouych technologii.

\section{Bibliografia}

Allen S., Newsy w sieci. Internet i dziennikarstwo, przeł. A. Sadza, Wydawnictuo Uniwersytetu Jagiellońskiego, Kraków 2008.

Anderson J., Rainie L., Vogels E.A., Experts Say the 'New Normal' in 2025 Will Be Far More Tech-Driven, Presenting More Big Challenges, Pew Research Center February 18, 2021, https://www.pewresearch.org/internet/2021/02/18/experts-say-the-new-normal-in-2025-will-be-far-more-tech-driven-presenting-more-big-challenges/ (dostęp: 12.08.2021).

Applebaum A., Zmierzch demokracji. Zwodniczy powab autorytaryzmu, przeł. P. Tarczyński, Wydawnictwo Agora, Warszawa 2020.

Beck U., Społeczeństwo światowego ryzyka. W poszukiwaniu utraconego bezpieczeństwa, przeł. B. Baran, Wydawnictwo Naukoue Scholar, Warszawa 2012.

Bond Potter C., Political Junkies. From Talk Radio to Twitter, How Alternative Media Hooked Us and Politics and Broke Our Democracy, Basic Books, New York 2020.

Castells M., Społeczeństwo sieci, przeł. M. Marody i in., Wydawnictwo Naukowe PWN, Warszawa 2008.

Castells M., Władza komunikacji, przeł. J. Jedliński, P. Tomanek, Wydawnictuo Naukoue PWN, Warszawa 2013.

Chadwick A., The Hybrid Media System, Oxford University Press, Oxford, UK 2013.

Curran J., Media and Power, Routledge, London-New York 2002.

Dang S., Maintenance error caused Facebook's 6-hour outage, company says, https:// wuw.reuters.com/technology/facebook-says-maintenance-error-caused-mondays-6-hour-outage-2021-10-05/ (dostęp: 5.10.2021).

DeNardis L., The Global War of Internet Governance, Yale University Press, New HavenLondon 2014.

Deuze M., Challenges and Opportunities for the Future of Media Mass Communication Theory and Research: Positionality, Integrative Research, and Public Scholarship, „Central European Journal of Communication” 2021, Vol. 14, No 1(28), s. 5-26.

Deuze M., The Role of Media and Mass Communication Theory in the Global Pandemic, „Communication Today” 2020, Vol. 11, No. 2, s. 5-16.

Dowbor L., Społeczeństwo w poszukiwaniu nowych kierunków, „Le Monde Diplomatique”, marzec-kwiecień 2021, s. 34-35.

Dukaj J., Wolność myśli albo demokracja, „Magazyn Wolna Sobota”, „Gazeta Wyborcza”, 5-6 czerwiec 2021, s. 9-11.

${ }_{58}$ J. Anderson, L. Rainie, E.A. Vogels, Experts Say the 'New Normal' in 2025..., s. 19. 


\section{Alicja Jaskiernia}

Dwoskin E., Tech giants are profiting - and getting more powerful - even as the global economy tanks, April 27, 2020, „The Washington Post”, https://www.washingtonpost.com/ technology/2020/04/27/big-tech-coronavirus-winners/ (dostęp: 17.08.2021).

Ebner J., Coraz ciemniej. Ekstremiści w sieci, przeł. A. Zieliński, Polityka Sp. z o.o., Warszawa 2020.

Fletcher R., Perception of fair news coverage among different groups, 2021 Digital News Report, Reuters Institute, https://reutersinstitute.politics.ox.ac.uk/digital-news-report/2021/ perceptions-fair-news-coverage-among-different-groups (dostęp: 17.08.2021).

Fuchs Ch., Everyday Life and Everyday Communication in Coronavirus Capitalism, „Communication, Capitalism \& Critique” 2020, Vol. 18 (1), s. 375-399.

Galloway S., Wielka Czwórka. Ukryte DNA: Amazon, Apple, Facebook i Google, przeł. J. Kubiak, Dom Wydawniczy Rebis, Poznań 2019.

Garton Ash T., Wolne stowo. Dziesięć zasad dla połaczonego świata, przeł. M. Godyń, F. Godyń, Społeczny Instytut Wydawniczy Znak, Kraków 2018.

Harari Yuval N., Wirus a śmierć, „Forum” 2020, nr 11, s. 25-27.

Henig R.M., Dlaczego świat nie byt gotowy na wirusa? Czy ignorowaliśmy sygnaty?, „National Geographic", 3.08.2020, https:/www.national-geographic.pl/artykul/koronawirus-brak-przygotowania-na-pandemie-dlaczego-ignorowalismy-sygnaly (dostęp: 12.08.2021).

Jaskiernia A., Information pollution in a digital and polarized world as a challenge to human rights protection - the Council of Europe's approach, ,Review of European and Comparative Law" 2021, Vol. XLVI, No. 3, s. 7-26.

Jaulmes A., Wojna na kliknięcia [Le Figaro], „Gazeta Wyborcza. Magazyn Wolna Sobota”, 19-20.06.2021.

Jenkins H., Ford S., Green J., Rozprzestrzenialne media. Jak powstają wartości i znaczenia $w$ usieciowionej kulturze, przeł. M. Wróbleuski, Wydawnictwo Uniwersytetu Łódzkiego, Łódź 2018.

Kitchen K., The New Superpowers: How and Why the Tech Industry is Shaping the International System, „National Affairs”, No. 48, Summer 2021, https://nationalaffairs.com/ the-new-superpowers-how-and-why-the-tech-industry-is-shaping-the-international-system (dostęp: 17.08.2021).

Kranzberg M., Technology and history: "Kranzberg's Laws”, „Bulletin of Science, Technology \& Society", First Published February 1, 1995, https://journals.sagepub.com/doi/ abs/10.1177/027046769501500104 (dostęp: 12.08.2021).

Krastew I., Nadesz ło jutro. Jak pandemia zmienia Europę, Wydawnictwo Krytyki Politycznej, Warszawa 2020.

Lau S., EU slams China's authoritian shift' and broken economic promises, „POLITICO”, 25.04.2021, https://wwu.politico.eu/article/eu-china-biden-economy-climate-europe/ (dostęp: 12.08.2021).

Levinson P., Nowe nowe media, przeł. M. Zawadzka-Strączek, Wydawnictuo WAM, Kraków 2010.

McNamee R., Nabici w Facebooka. Przestroga przed katastrofa, przeł. K. Pułauski, Media Rodzina Sp. z o.o., Poznań 2019.

Mendelson B.J., Social Media to ściema, przeł. M. Machnik, Wydawnictuo Helion, Gliwice 2014.

Mitchell A., Jurkowitz M., Baxter Oliphant J., Shearer E., Political Divides, Conspiracy Theories and Divergent News Sources Heading Into 2020 Election, Pew Research Center, September 16, 2020, https://www.journalism.org/2020/09/16/ 
„Nowa normalność" czy zmiana paradygmatu?...

political-divides-conspiracy-theories-and-divergent-neus-sources-heading-into-2020-election/ (dostęp: 17.08.2021).

Morozov E., To Save Everything, Click Here, Penguin Books, London 2013.

Okno. Olga Tokarczuk o pandemii, 3.04.2020, CULTURE.PL, https://culture.pl/pl/artykul/ okno-olga-tokarczuk-o-pandemii (dostęp: 12.08.2021).

Orłouski M., Globalny wyścig o zachowanie podmiotowości, Idee dla Polski. Obywatelski thinkletter, https://www.kongresobywatelski.pl/wpcontent/uploads/2019/01/mariusz_orlowski-globalny_wyscig_o_zachowanie_podmiotowosci.pdf (dostęp: 2.11.2021).

Rainie L., Anderson J., Albright J., The Future of Free Speech, Trolls, Anonymity and Fake News Online, Pew Research Center, March 2017, https://www.pewresearch.org/internet/2017/03/29/the-future-of-free-speech-trolls-anonymity-and-fake-neus-online/ (dostęp: 17.08.2021).

Schwab K., Czwarta rewolucja przemystowa, przeł. A.D. Kamińska, Wydawnictwo Studio EMKA, Warszawa 2018.

Strittmatter K., Chiny 5.0. Jak powstaje cyfrowa dyktatura, przeł. A. Gadzała, Grupa Wydawnicza Foksal, Warszawa 2018.

Warren E., Here's how we can break up Big Tech (March 8, 2019), https://medium.com/@ teamwarren/heres-how -we -can- break- up-bigTtech (dostęp: 17.08.2021).

Zuboff S., Wiek kapitalizmu inwigilacji. Walka o przyszłość ludzkości na nowej granicy władzy, przeł. A. Unterschuetz, Wydawnictwo Zysk i S-ka, Poznań 2020. 